\title{
Nuclear waste problem solved, claims Sweden's nuclear industry
}

"WE are not going to leave any waste around that is going to harm anybody." So says Asea-Atom's Dr Kåre Hanners, one of the authors of a just-published report which asserts that the Swedish nuclear power industry has found a way of safely storing unreprocessed, spent fuel from nuclear reactors for hundreds of thousands of years.

According to the report, "Nuclear Fuel Safety Project 2", spent, unreprocessed fuel would first be stored in water pools for 40 years. It would then be loaded into 4.5 metre-long canisters, each made of 15 tons of copper, with walls $20 \mathrm{~cm}$ thick. The space between the fuel and the canister walls would then be filled with lead, and each canister finally deposited in its own tunnel off a shaft drilled 500 metres down into bedrock.

After being drilled, each tunnel would have been lined with compressed bentonite, which swells to ten times its own volume on contact with water if it is not constricted. If it is constricted, as it would be in the tunnel, its pressure increases until it becomes almost totally impermeable. When the canister had been deposited in the tunnel, all the space left would be sealed with more bentonite, and a mixture of bentonite and quartz sand would be used to fill the shaft after all the tunnels were full.

In this way, the report maintains, corrosion of the canisters would be so small that it would not damage their integrity for thousands of years, and any waste which eventually did escape would be prevented by the action of the bentonite from being carried by the geological transport of water through the rock to the biosphere.

With the publication of this report, the nuclear power industry is making a final plea for its survival. Faced in 1977 by the new coalition government's so-called Stipulation Law, requiring owners of nuclear reactors to show how and where they could store with complete safety either high-level reprocessed waste or unreprocessed, spent fuel, the power industry decided to give top priority to showing that it could meet the challenge. All normal research and development within the industry stopped, while 200 to 300 of its own researchers as well as consultants from various universities concentrated all their energies on this one project.

The effort, which cost well over 10 million, has resulted in two reports: one, published last year, on the handling of spent fuel and final storage of vitrified, high-level waste, and this second one. The first report has been reviewed by many Swedish and foreign bodies and has mainly been approved, although there have also been many criticisms. These have often concerned the reprocessing agreement concluded on behalf of the industry with the French firm Cogema. The agreement is secret and not even the government's official reviewers of the safety of the industry's proposals have been allowed to see it: a plainly ludicrous situation. It is hardly surprising that French inexperience and inefficiency reportedly bordering on chaos in reprocessing the light water reacior fuel that Sweden uses, plus reports that the agreement contains an absolute escape clause for Cogema with no guarantee to reprocess at all in the event of major technical hindrances, and the fact that the agreement covers only reprocessing in the 1980 s rather than for the whole 30 year lifetime of a new reactor, have raised the question of whether the contract can be "adequate", as demanded by the Stipulation Law.

Anti-nuclear groups have challenged the first report on other grounds as well. They say, for example, that the canisters designed for transporting spent fuel to and from the reprocessing plan would not be able to withstand pressures of long immersion in case of shipwreck; that the storage facilities would need security measures that would infringe democratic rights; that various technical difficulties have been underestima ed such as the sealing off of the openings to the final repository shafts to prevent Icakage of ground water; that the stability of Swedish bedrock is not as great as the industry supposes; and that research findings unpalatable to the industry have been suppressed.

In the face of these assertions and counter-assertions between pro- and anti-nuclear groups, each of whom suspects by now even the motives and mentality of the other, and reflecting the extremely tight political situation in which the Prime Minister's party has sworn it will do away with nuclear power but faces enormous pressure in the opposite direction from its coalition partners, the government has still not pronounced on the overdue question of whether the loading of the Ringhals 3 and Forsmark 1 reactors can go ahead. Their owners have, under the Stipulation Law, applied for permission to load and to reprocess the spent fuel, and both reactors are standing ready for operation. Although Energy Minister Olof Johansson has promised to let them know in August and to present a new energy policy in December, it seems likely that the owners may be kept waiting even longer than that. In fact. on practically every aspect of current energy policy, the government could well adopt as its slogan the words of a former Australian Prime Minister: "The government's position is clear. It has not made up its mind."Wendy Barnaby

\section{Shcharanskii trial delayed again, others exiled}

According to Soviet law, Anatolii Shcharanskii, the Moscow mathematician and human rights campaigner, who has been in custody facing possible treason charges since March 1977, should have been brought to trial not later than 15 December 1977. By special permission of the Supreme Soviet, this period of pre-trial intention was extended to 15 June 1978. Although this extension period has now expired, there are still no indications that Shcharanskii will either be brought to trial or released from custody in the near future.

Meanwhile, however, several of his fellow activists have been removed from Moscow. On 17 May, Josif Begun, a cyberneticist, just returned from a sentence of two years' Siberian exile, was arrested on a charge of residing in Moscow without the necessary permissions. He has since been sentenced to a further 3 years exile.

On 1 June, Vladimir Slepak, an electronics engineer, and his wife were arrested for "malicious hooliganism" (in fact, for making a peaceful demonstration-a right specifically guarantced under Article 50 of the new Soviet constitution). Slepak has now been sentenced to 5 years' Siberian exile, and it is feared that a similar sentence may be imposed on his wife, who is at present in hospital with duodenal ulcers. Begun and Slepak are both to appeal against the sentences.

Like Shcharanskii, Slepak combined his involvement in the Jewish emigration movement with membership of the illicit "Helsinki Monitoring Group". His son told Nature recently that his father did not see how the .Jewish demand for emigration could be divided from the overall human rights movement. "The right to emigrate is one of the fundamental human rights," he said. "So it is no good saying "You eat your apple and I'll eat my apple.' Now we are hoth biting into the same we are both biting into the Same 